Article

\title{
Exopolysaccharides Producing Bacteria for the Amelioration of Drought Stress in Wheat
}

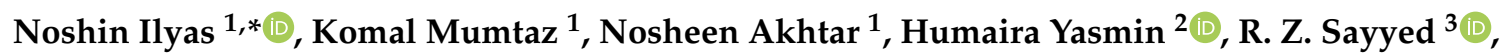 \\ Wajiha Khan 4®D, Hesham A. El Enshasy 5,6,7,*, Daniel J. Dailin 5,6, Elsayed A. Elsayed ${ }^{8,9}$ (®) and \\ Zeshan Ali ${ }^{10}$ \\ 1 Department of Botany, PMAS Arid Agriculture University, Rawalpindi 46300, Pakistan; \\ komalmumtaz070@gmail.com (K.M.); noshee.nawaz444@gmail.com (N.A.) \\ 2 Department of Biosciences, COMSATS University, Islamabad 45550, Pakistan; \\ humaira.yasmin@comsats.edu.pk \\ 3 Department of Microbiology, PSGVP Mandal's Arts, Science and Commerce College, \\ Shahada 425409, Maharashtra, India; sayyedrz@gmail.com \\ 4 Department of Biotechnology, COMSATS University Islamabad, Abbottabad Campus, \\ Abbottabad 22010, Pakistan; wajihak@cuiatd.edu.pk \\ 5 Institute of Bioproduct Development (IBD), Universiti Teknologi Malaysia (UTM), \\ Skudai 81310, Johor, Malaysia; jddaniel@utm.my \\ 6 School of Chemical and Energy Engineering, Faculty of Engineering, Universiti Teknologi Malaysia (UTM), \\ Skudai 81310, Johor, Malaysia \\ 7 City of Scientific Research and Technology Applications (SRTA), New Burg Al Arab 21934, Alexandria, Egypt \\ 8 Zoology Department, College of Science, King Saud University, P.O. 2455, Riyadh 11451, Saudi Arabia; \\ eaelsayed@ksu.edu.sa \\ 9 Chemistry of Natural and Microbial Products Department, National Research Centre, Dokki, Cairo 11651, Egypt \\ 10 Plant Physiology Program, Crop Sciences Institute, National Agricultural Research Centre, Park Road, \\ Islamabad 45500, Pakistan; eco4nd@yahoo.com \\ * Correspondence: noshinilyas@yahoo.com (N.I.); henshasy@ibd.utm.my (H.A.E.E.)
}

Received: 4 October 2020; Accepted: 23 October 2020; Published: 26 October 2020

check for updates

\begin{abstract}
This research was designed to elucidate the role of exopolysaccharides (EPS) producing bacterial strains for the amelioration of drought stress in wheat. Bacterial strains were isolated from a farmer's field in the arid region of Pakistan. Out of 24 isolated stains, two bacterial strains, Bacillus subtilis (Accession No. MT742976) and Azospirillum brasilense (Accession No. MT742977) were selected, based on their ability to produce EPS and withstand drought stress. Both bacterial strains produced a good amount of EPS and osmolytes and exhibited drought tolerance individually, however, a combination of these strains produced higher amounts of EPS (sugar $6976 \mu \mathrm{g} / \mathrm{g}, 731.5 \mu \mathrm{g} / \mathrm{g}$ protein, and $1.1 \mathrm{mg} / \mathrm{g}$ uronic acid) and osmolytes (proline $4.4 \mu \mathrm{g} / \mathrm{mg}$ and sugar $79 \mu \mathrm{g} / \mathrm{mg}$ ) and significantly changed the level of stress-induced phytohormones $(61 \%, 49 \%$ and $30 \%$ decrease in Indole Acetic Acid (IAA), Gibberellic Acid (GA), and Cytokinin (CK)) respectively under stress, but an increase of $27.3 \%$ in Abscisic acid (ABA) concentration was observed. When inoculated, the combination of these strains improved seed germination, seedling vigor index, and promptness index by $18.2 \%$, $23.7 \%$, and $61.5 \%$ respectively under osmotic stress ( $20 \%$ polyethylene glycol, PEG6000). They also promoted plant growth in a pot experiment with an increase of $42.9 \%, 29.8 \%$, and $33.7 \%$ in shoot length, root length, and leaf area, respectively. Physiological attributes of plants were also improved by bacterial inoculation showing an increase of $39.8 \%, 61.5 \%$, and $45 \%$ in chlorophyll a, chlorophyll $b$, and carotenoid content respectively, as compared to control. Inoculations of bacterial strains also increased the production of osmolytes such asproline, amino acid, sugar, and protein by $30 \%, 23 \%$, $68 \%$, and $21.7 \%$ respectively. Co-inoculation of these strains enhanced the production of antioxidant enzymes such as superoxide dismutase (SOD) by $35.1 \%$, catalase (CAT) by $77.4 \%$, and peroxidase (POD) by $40.7 \%$. Findings of the present research demonstrated that EPS, osmolyte, stress hormones,
\end{abstract}


and antioxidant enzyme-producing bacterial strains impart drought tolerance in wheat and improve its growth, morphological attributes, physiological parameters, osmolytes production, and increase antioxidant enzymes.

Keywords: antioxidant enzymes; Azospirillum brasilense; Bacillus subtilis; stress hormones; osmolytes; plant growth promotion; wheat

\section{Introduction}

Wheat is a staple food used worldwide and its demand will increase with the growing population. It is assumed that its production needs to be increased by $50 \%$ by the year 2030 [1]. Wheat and other crop plants are continuously exposed to various biotic and abiotic stress factors that reduce plant growth and productivity. Abiotic stress factors include heat, salinity, chilling, nutrient deficiency, and drought. Climate change is predicted to increase the severity of extreme weather which may affect crop production worldwide. In the current situation, periodic drought is the main cause of reducing the global productivity of plants including wheat [2]. Drought stress is caused by the limited availability of water in the soil which ultimately reduces turgor, nutrient absorption, growth, and yield of plants. Stomatal closure results in decreased photosynthetic rates in plants. Plants adjust their vital processes to combat drought stress. However, the plant responses are controlled by their genetic makeup and the duration of the drought stress [3].

There is a need to develop and promote environment-friendly strategies to cope with drought stress. Inoculation of plant growth-promoting rhizobacteria (PGPR) in the rhizosphere of crops is one of the most suitable strategies in agriculture [4]. The PGPR is a group of beneficial soil bacteria that not only improve the growth of the plants but also enhance drought tolerance in plants [5]. There are several mechanisms by which PGPR work efficiently under stress. The reported mechanisms include the production of stress-related hormones, osmolytes, antioxidant enzymes; exopolysaccharides (EPS), etc. [6]. Under water stress, the inoculation of EPS producing PGPR strains improves plant growth [7]. Literature reports that EPS changes soil structure and improves root/shoot growth. As a result of the change in the rhizosphere, plants expand their root system which enhances the nutrient and water uptake. It also detoxifies free radicals and reduces the negative effects of reactive oxygen species (ROS) [8]. EPS-producing strains have been also reported to produce antioxidant enzymes i.e., superoxide dismutase (SOD), catalase (CAT), and peroxidase (POD), which detoxify ROS, therefore the ability of PGPR to augment the antioxidants can help in imparting drought tolerance. On the other hand, osmotic adjustment is also the key adaptation at the cellular level. It is the accumulation of organic and inorganic solutes at the cellular level which maintain the cells' turgor properties and also protect proteins, enzymes, membranes, and cellular organelles from oxidative damage [9]. Proline is one of the prominent osmolytes produced in drought stress. It scavenges free radicals and stabilizes sub-cellular structures. The PGPR inoculation is known to improve proline levels and antioxidant activities and thus help plants to withstand drought or any other abiotic stress conditions [10].

Though rhizobacterial inoculations have been studied in cereals, however, identification and investigation of the role of EPS producing PGPR strains in combating drought conditions still need in-depth exploration. This research hypothesized that EPS producing PGPR are less prone to drought and their inoculation in the rhizosphere ameliorates the negative impacts of drought stress in wheat. This study elucidates the role of EPS producing PGPR on germination, physiological, morphological, and biochemical parameters of wheat under drought stress. 


\section{Materials and Methods}

\subsection{Collection of Soil Samples and Isolation of Bacteria from Soil}

Two soil samples were collected from topsoil (6 inches) of farmer's fields at the arid region of Bahawalpur, $\left(29^{\circ} 25^{\prime} 5.0448^{\prime \prime} \mathrm{N}-71^{\circ} 40^{\prime} 14.4660^{\prime \prime}\right.$ E) Pakistan. A composite sample was obtained from each location. Soil samples were stored in plastic bags and were brought to the laboratory where they were stored at $4{ }^{\circ} \mathrm{C}$, before further use. The soil samples were analyzed for physico-chemical characteristics by following the method of Li et al. [11].

The serial dilution method was followed for the isolation of bacteria from the two soil samples. One gram of soil sample was suspended in $9 \mathrm{~mL}$ of distilled water. This soil suspension was stirred with a magnetic stirrer for $1 \mathrm{~h}$ followed by centrifugation $(3000 \mathrm{rpm})$ for $10 \mathrm{~min}$. Supernatant was used to prepare decimal dilutions and the resulting aliquots $(20 \mu \mathrm{L})$ were spread on Luria-Bertani (LB) agar plates and nitrogen-free bromothymol (NFB) semisolid media of the following composition $(\mathrm{g} / \mathrm{L}) ; \mathrm{KOH}$ 4.0, DL-Malic acid 5.0, $\mathrm{K}_{2} \mathrm{HPO}_{4}$ 0.5, $\mathrm{MnSO}_{4} \cdot \mathrm{H}_{2} \mathrm{O} 0.01, \mathrm{FeSO}_{4} .7 \mathrm{H}_{2} \mathrm{O} 0.05, \mathrm{MgSO}_{4} .7 \mathrm{H}_{2} \mathrm{O}$ 0.1, $\mathrm{CaCl}_{2} \cdot 2 \mathrm{H}_{2} \mathrm{O}$ $0.01, \mathrm{NaCl} 0.02, \mathrm{Na}_{2} \mathrm{MoO}_{4} \cdot 2 \mathrm{H}_{2} \mathrm{O} 0.002$, agar-agar 1.75 , bromothymol blue $2 \mathrm{~mL}$ ( $0.5 \%$ alcoholic solution) and distilled water $1000 \mathrm{~mL}$. The $\mathrm{pH}$ of the medium was adjusted to 6.8 and incubation was done at 28 ${ }^{\circ} \mathrm{C}$ for 2 days. Pure cultures were obtained through streaking the colonies $4-5$ times on LB agar by dilution plate technique until a single pure colony appeared [12].

\subsection{Characterization of Bacterial Isolates}

Isolates were identified based on colony morphology (shape, margin, size, elevation, texture, appearance, optical properties, and pigmentation) as well as for cellular characteristics (cell shape, motility, gram staining) [13]. Each of the purified bacterial isolates was evaluated for its plant growth promotion (PGP) characteristics.

The phosphorous solubilization ability of the isolates was checked by their production of cleared zones around the colonies in the Pikovaskaya'sagar. Phosphomolybdate blue color method was used to measure the total solubilized phosphate [14]. Slightly modified Pikovoskaya'smedium was inoculated with each strain followed by incubation at $30^{\circ} \mathrm{C}$ for 5 days. After incubation, the broths were centrifuged for $15 \mathrm{~min}$ at $6000 \mathrm{rpm}$. A mixture of the supernatant $(500 \mu \mathrm{L})$ and 2,4-dinitrophenol $(40 \mu \mathrm{L}$ ) was added to $20 \mu \mathrm{L}$ of dilute sulfuric acid, following the addition of $5 \mathrm{~mL}$ of chromogenic reagent. The resulting mixture was diluted using sterilized water to make the total volume up to $50 \mathrm{~mL}$ and absorbance $(680 \mathrm{~nm})$ was recorded.

Siderophore production was tested according to the modified method of Patel et al. by spot inoculation on Chrome Azurol S (CAS) media [15]. Each of the bacterial strains was spot inoculated on petri plates containing CAS media. An un-inoculated plate was considered as control. The inoculated CAS medium plates were incubated for approximately a week at $28^{\circ} \mathrm{C}$ and the colonies thus obtained were observed for the production of the orange zone around the bacterial colonies.

Each of the bacterial isolates was also checked for its ability to produce hydrogen cyanide (HCN) following the method of Lorck [16]. Nutrient agar medium (pre-soaked in $2 \%$ sodium carbonate $w / v$ and $0.5 \%$ picric acid) was streaked with bacterial strains supplemented with $4.4 \mathrm{~g} / \mathrm{L}$ of glycine. The inoculated plates were sealed with para-film paper and incubated at $28^{\circ} \mathrm{C}$ for 4 days. The development of color (orange or red) is an indication of the production of $\mathrm{HCN}$.

A series of conventional biochemical tests were carried out (according to Bergey's Manual of Systematic Bacteriology) to characterize the isolated bacteria [17]. The carbon/nitrogen (C/N) source utilization pattern of bacterial isolates was determined using QTS-24 kits. The isolates were then tested for their drought tolerance by growing each of them in LB agar supplemented with different levels $(5 \%, 10 \%, 15 \%, 30 \%, 25 \%)$ of PEG 6000 [16]. 
PCR-Amplification and $16 \mathrm{~S}$ rRNA Sequence Analysis

DNA was extracted from pure cultures of each strain grown in LB broth as described by Chen and Kuo [18]. Amplification of genomic DNA of bacterial isolates was carried out according to the method Weisburg et al. [19]. The primer used for PCR-amplification has the nucleotide sequence of ( $\mathrm{fd} 1$ ) AGAGTTTGATCCTGGCTCAG, and reverse primer (rd1) (AAGGAGGTGATCCAGCC). The amplified PCR product was purified and sequenced on an automated sequencer by gel purification kits (JET quick, Gel Extraction Spin Kit, GENOMED). The strains were identified by using a nearly complete sequence of 16S rRNA gene on (BLAST) NCBI by comparing sequence and phylogenetic relatedness with the known organisms.

\subsection{Assessment of Drought Tolerance}

Drought tolerance of the two selected bacterial strains was tested by culturing them in a flask containing $50 \mathrm{~mL}$ of nutrient broth medium supplemented with $10 \%$ and $20 \%$ polyethylene glycol (PEG6000). For the combination, the isolates were grown in $100 \mathrm{~mL}$ nutrient broth (NB) and were incubated at $28^{\circ} \mathrm{C}, 150 \mathrm{rpm}$ for $24 \mathrm{~h}$. The cells were separated via centrifugation at $4000 \mathrm{rpm}$ for $15 \mathrm{~min}$, and the pellet was suspended in $10 \mathrm{~mL}$ sodium chloride $(\mathrm{NaCl} ; 0.85 \mathrm{~g})$ normal saline for preparation of standard inoculums. The growth of each isolate was monitored by measuring the absorbance at $550 \mathrm{~nm}$ by using a spectrophotometer till the optical density 0.5 , calculated for both isolates as $10 \%(v / v)$ of standard inoculate. Then, $10 \%(v / v)$ of standard inoculate was transferred into $100 \mathrm{~mL}$ of the medium with $10 \%$ and $20 \%$ polyethylene glycol and incubated for 7 days at $28{ }^{\circ} \mathrm{C}$ in a shaker at $150 \mathrm{rpm}$. Their growth rate was analyzed by using the protocol described by Mishra [20]. The concentration of osmolytes was also measured by following the protocol of Hodge and Hofreiter [21].

\subsection{EPS Emulsification Activity of Bacterial Strains}

Bacterial strains were also tested for EPS-emulsification activity by following the protocol described by Rosenberg et al. [22]. Lyophilized EPS $(0.5 \mathrm{mg})$ was dissolved in distilled water $(0.5 \mathrm{~mL})$ by heating at $65^{\circ} \mathrm{C}$ for $\sim 20 \mathrm{~min}$, later cooled at room temperature. The total volume was made $2 \mathrm{~mL}$ by adding phosphate buffer saline (PBS) to the EPS solution. This mixture was supplemented with hexadecane $(0.5 \mathrm{~mL})$ and vortexed for $5 \mathrm{~min}$. The absorbance of the resulting solution was taken instantly after vortex $\left(A_{0}\right)$ using a spectrophotometer at $540 \mathrm{~nm}$. Another reading of absorbance was taken after incubating the mixture at room temperature for 30 and $60 \mathrm{~min}\left(A_{t}\right)$. For the emulsifying activity of $\mathrm{EPS} \%$ retention after incubation time was calculated as;

$$
t=A_{t} / A_{0} \times 100
$$

A control (blank) was prepared as a mixture of hexadecane $(0.5 \mathrm{~mL})$ and PBS $(2 \mathrm{~mL})$.

\subsection{Quantification of EPS Substances}

Polysaccharide extraction and analysis were done by using the protocol of Naseem and Bano et al. [23]. The bacterial strains were cultured in optimized mineral salts medium with $18.2 \% \mathrm{KH}_{2} \mathrm{PO}_{4}, 12.6 \% \mathrm{~K}_{2} \mathrm{HPO}_{4}, 0.6 \% \mathrm{MnSO}_{4}, 10 \% \mathrm{NH}_{4} \mathrm{NO}_{3}, 0.06 \% \mathrm{FeSO}_{4} \cdot 2 \mathrm{H}_{2} \mathrm{O}, 1 \% \mathrm{CaCl}_{2} .2 \mathrm{H}_{2} \mathrm{O}$, $1 \% \mathrm{MgSO}_{4} .7 \mathrm{H}_{2} \mathrm{O}, 1.5 \% \mathrm{NaCl}, 1 \%$ sodium molybdate, and $0.2 \%$ of glucose in $1 \mathrm{~L}$ of distilled water for 10 days. The bacterial cultures $(250 \mathrm{~mL})$ were centrifuged at $15,000 \mathrm{rpm}$ at $4{ }^{\circ} \mathrm{C}$ for $20 \mathrm{~min}$. The supernatant was used to extract the EPS by the addition of two-fold ice-cold ethanol (95\%). For complete precipitation, the solution was chilled at $4{ }^{\circ} \mathrm{C}$. The EPS was obtained from the chilled solution. The solubility of EPS was determined by suspending small quantities of lyophilized EPS in $2 \mathrm{~mL}$ of chloroform, benzene, acetone, water, ethanol, and methanol. Pellet formation was observed after the mixture was vortexed and allowed to stabilize for some time. The concentration of protein, total soluble sugar, and uronic acid was determined by using the protocols of Lowrey et al. [24], 
Dubois et al. [25], and Taylor and Buchanan [26], respectively. The medium without inoculum was used as the blank.

\subsection{Screening and Production of Phytohormones}

The ability of two drought-tolerant strains to produce phytohormones such as indole acetic acid (IAA), gibberellic acid (GA), abscisic acid (ABA), and cytokinins (CK) in the culture media was determined according to the method of Tien et al. [27]. The hormone extraction was carried out by centrifugation of the cultured broths at 10,000 rpm for $15 \mathrm{~min}$ followed by adjustment of $\mathrm{pH}$ (2.8) with $1 \mathrm{~N} \mathrm{HCl}$ and addition of an equal volume of ethyl acetate. The residue obtained after the evaporation of the solution at $35^{\circ} \mathrm{C}$, was mixed with $1500 \mu \mathrm{L}$ of methanol. Finally, the samples were run on HPLC (Agilent 1100, Germany) equipped with a C18 column $(39 \times 300 \mathrm{~mm})$ and a UV detector. For standardization of HPLC, pure grade hormones; CK, ABA, IAA, and GA (Sigma Chemical Co., St. Louis, MO, USA) were dissolved in HPLC grade methanol. The absorbance wavelength used for the detection was as follows; ABA, GA, and CKat $254 \mathrm{~nm}$, IAA at $280 \mathrm{~nm}$. The LB medium without any inoculum was used as the blank.

\subsection{Germination Experiment}

The germination experiment was performed in the Plant Physiology Laboratory of PMAS Arid Agriculture University, Rawalpindi, Pakistan. Seeds of two wheat varieties, Pak 13 and NARC 09, were obtained from the National Agricultural Research Centre, Islamabad, Pakistan. Surface sterilization of seeds was done by $0.2 \%$ sodium hypochlorite for $5 \mathrm{~min}$ and later washed with distilled water. Drought tolerant bacterial strains, identified as Bacillus subtilis and Azospirillum brasilense, which also showed EPS secreting abilities, were used in this experiment. These bacterial strains and their combination were grown in LB broth in an incubator shaker for $48 \mathrm{~h}$ at $28^{\circ} \mathrm{C}$. After centrifugation at $4000 \mathrm{rpm}$ for $10 \mathrm{~min}$, the pellet was mixed with distilled water and optical density was adjusted at 1 (at $660 \mathrm{~nm}$ ) for obtaining the final concentration of $10^{8} \mathrm{CFU} / \mathrm{mL}$. Seeds were primed with B. subtilis and A. brasilense and their combination (as mentioned in Section 2.3) at $26 \pm 2{ }^{\circ} \mathrm{C}$ for $4 \mathrm{~h}$. Ten seeds were placed per petri plate and the treatments included; control, PEG (6000) $20 \%$ exposed seeds, and seeds primed with B. subtilis, A. brasilense, and the combination were placed in both normal and water-stressed conditions. Germination parameters like germination percentage, seedling vigor index (S.V.I), and promptness index (P.I) were measured.

\subsection{Pot Experiment}

A pot experiment was conducted in the glasshouse of PMAS Arid Agriculture University, Rawalpindi, Pakistan. Pots having $10 \mathrm{~kg}$ capacity were filled with soil and kept in the glasshouse. For each treatment, three replicates were taken and four plants were maintained per pot. Seeds of wheat varieties i.e., Pak 13 and NARC 09, were obtained from the National Agricultural Research Centre and sterilized by using $0.2 \%$ sodium hypochlorite. Seven seeds were planted per pot and thinning was done after germination to maintain four healthy plants per pot. The culture of bacterial isolates was used for the germination experiment (B. subtilis, A. brasilense, and combination, broth $10^{8} \mathrm{CFU} / \mathrm{mL}$ ). Hundred $\mathrm{mL}$ of LB broth was used to grow the bacterial strains at $28 \pm 2{ }^{\circ} \mathrm{C}$ for $48 \mathrm{~h}$. The bacterial cells were harvested by centrifugation at $6000 \times g$ for $10 \mathrm{~min}$ and washed with phosphate-buffered saline (PBS). The final pellet was resuspended in PBS and cell density was adjusted to $10^{8} \mathrm{CFU} / \mathrm{mL}$. The sterilized seeds were soaked into bacterial cell suspensions for $4 \mathrm{~h}$. The uninoculated plant seeds soaked in sterile water only served as control. Uninocualted and inoculated seeds were sown in pots. Drought stress was induced after 1 month by withholding water and maintaining field capacity at $45 \%$. After 15 days of imposing stress, different parameters i.e., morphological, physiological, and biochemical were analyzed. 


\subsection{Morphological Parameters}

Morphological parameters like root length, shoot length, and leaf area were measured. Leaf area was measured with the help of a leaf area meter.

\subsection{Physiological Parameters}

\subsubsection{Membrane Stability Index Percentage (MSI\%)}

Leaves were collected and washed with distilled water. Then leaves were placed in test tubes having $10 \mathrm{~mL}$ distilled water and were kept in a water bath at $40{ }^{\circ} \mathrm{C}$ for $30 \mathrm{~min}$, and electrical conductivity (C1) was recorded. Later, the same samples were placed in a water bath for $10 \mathrm{~min}$ at $100{ }^{\circ} \mathrm{C}$ and electrical conductivity (C2) was noted. The membrane stability index was calculated by using the formula [28].

$$
\mathrm{MSI} \%=[1-\mathrm{C} 1 / \mathrm{C} 2] \times 100
$$

\subsubsection{Estimation of Chlorophyll Content}

Chlorophyll content was estimated by following the protocol of Bruinsama [29]. One gram of leaf was ground and homogenized in $80 \%$ acetone followed by centrifugation and measurement of absorbance at $470 \mathrm{~nm}, 663 \mathrm{~nm}$, and $645 \mathrm{~nm}$ in UV-Visible spectrophotometer (Labomed UVD 3500, Los Angeles, CA, USA).

\subsubsection{Estimation of Water Potential and Osmotic Potential}

The water potential of leaves was estimated by using a pressure chamber [30]. The osmotic potential was measured by using the protocol of Capell and Doerffling [31]. Leaves were placed in Eppendorf tubes and were frozen for 2 weeks. Afterward, the cell saps were collected and osmotic potential was recorded by using an osmometer.

\subsection{Biochemical Parameters}

\subsubsection{Estimation of Proline Content}

Proline contents were determined by following the protocol of Bates [32]. The filtrate of fresh leaves $(0.5 \mathrm{~g})$ homogenized with $3.0 \%$ of sulfosalicylic acid $(10 \mathrm{~mL})$ was mixed with equal amounts of ninhydrin reagent ( $1.25 \mathrm{~g}$ ninhydrin in $30 \mathrm{~mL}$ glacial acetic acid and $20 \mathrm{~mL} 6 \mathrm{M}$ phosphoric acid) and glacial acetic acid ( $100 \%$ pure, Sigma Aldrich). The mixture was heated in a water bath at $90{ }^{\circ} \mathrm{C}$ and the reaction was stopped after $1 \mathrm{~h}$ by transferring the mixture to ice. Toluene $(1 \mathrm{~mL})$ was added to the mixture and the resulting solution was separated into two distinct layers. Among these, the upper layer was used to determine the proline content by measuring the absorbance at $520 \mathrm{~nm}$ and using the proline standard curve.

\subsubsection{Estimation of Amino Acid Content}

The extract was prepared for the analysis of amino acid content by following the method of Hamilton and Vanslyke [33]. Leaf extract $(1 \mathrm{~mL})$ was mixed with $1 \mathrm{~mL}$ of $80 \%$ ethanol, $1 \mathrm{~mL}$ of $0.2 \mathrm{M}$ citrate buffer ( $\mathrm{pH}-5)$, and $2 \mathrm{~mL}$ of the ninhydrin reagent. A spectrophotometer was used to measure the absorbance of the reaction mixture at $570 \mathrm{~nm}$. The amino acids present in the samples were calculated using the following equation;

$$
\text { Amino acids }=\frac{\text { Absorbance } \times \text { Volume } \times \text { Diluted concentration }}{\text { Weight of Plant Sample }} \times 1000
$$

The standard curve was prepared by using the amino acid leucine and results were expressed in $\mathrm{mg}$ of amino acid per gram of dry tissue. 


\subsubsection{Estimation of Soluble Protein Content}

Soluble protein content was estimated by Bradford assay [34]. Proteins were extracted by dissolving leaf samples $(0.2 \mathrm{~g})$ in $4 \mathrm{~mL}$ of sodium phosphate buffer $(\mathrm{pH} 7)$, and $0.5 \mathrm{~mL}$ of the extract was mixed with $3 \mathrm{~mL}$ of Coomassie bio red dye. Bovine serum albumin was used as a standard. Protein content was determined by measuring the optical density of the solution at $595 \mathrm{~nm}$ and using a protein standard curve.

\subsubsection{Estimation of Soluble Sugar Content}

Soluble sugar content was determined by using the protocol of Dubois et al. [35]. Ground plant tissue $(0.1 \mathrm{~g})$ was mixed with $80 \%$ methanol $(3 \mathrm{~mL})$. The solution was heated in a water bath at $70{ }^{\circ} \mathrm{C}$ for $30 \mathrm{~min}$. An equal volume of $5 \%$ phenol and $0.5 \mathrm{~mL}$ extract was mixed with $1.5 \mathrm{~mL}$ of concentrated sulfuric acid and was again incubated in the dark for $30 \mathrm{~min}$. The absorbance of the sample was checked at $490 \mathrm{~nm}$. The standard curve for glucose solution was prepared which was used for the determination of the sugar content, expressed in $\mathrm{mg} / \mathrm{g} / \mathrm{FW}$.

\subsection{Estimation of Antioxidant Enzymes}

Leaf $(1 \mathrm{~g})$ was ground in liquid nitrogen to get the enzyme extract. The obtained powder was added to $50 \mathrm{mM}$ phosphate buffer $(10 \mathrm{~mL})$ at $\mathrm{pH} 7.0$ and was then mixed with $1 \mathrm{mM}$ ethylene diamine tetraacetic acid (EDTA) and 1\% polyvinylpyrrolidone (PVP). The whole mixture was spun at 13,000×g for $20 \mathrm{~min}$ at $4{ }^{\circ} \mathrm{C}$. The resulting supernatant was used for the enzyme assay.

The SOD activity was measured by monitoring the inhibition in the photoreduction of nitro blue tetrazolium (NBT). The reaction mixture contained $130 \mathrm{mM}$ methionine, $0.75 \mathrm{mM} \mathrm{NBT}, 0.05 \mathrm{M}$ phosphate buffer ( $\mathrm{pH} 7.0$ ), $0.02 \mathrm{mM}$ riboflavin and $300 \mu \mathrm{L}$ enzyme extract. The reaction mixture and blank were exposed to fluorescent light for $7 \mathrm{~min}$ and absorbance was taken at $560 \mathrm{~nm}$ [36]. The CAT activity was determined by the change in absorbance due to $\mathrm{H}_{2} \mathrm{O}_{2}$ at $240 \mathrm{~nm}$ for $1 \mathrm{~min}$ [37]. The CAT activity (U/mg protein) was estimated from the molar absorption coefficient of $40 \mathrm{~mm}^{-1} \mathrm{~cm}^{-1}$ for $\mathrm{H}_{2} \mathrm{O}_{2}$. The POD activity was detected according to the method of Zhang and Karkim [38]. The reaction mixture consisted of $10 \mu \mathrm{L}$ of crude enzyme extract, $10 \mu \mathrm{L}$ of $100 \mathrm{mM} \mathrm{H}_{2} \mathrm{O}_{2}, 160 \mu \mathrm{L}$ of $50 \mathrm{mM}$ sodium acetate (pH 5.0), and $20 \mu \mathrm{L}$ of $100 \mathrm{mM}$ guaiacol. Absorbance was recorded at $450 \mathrm{~nm}$.

\subsection{Statistical Analysis}

Analysis of variance (ANOVA) was carried out to investigate the effects of drought stress on the accumulation of osmolytes and phytohormones in EPS producing A. brasilense, B. subtilis, and their combination. Similarly, differences in emulsification activity $(\%)$ and lyophilized chemical composition of EPS of A. brasilense, B. subtilis, and their combinations were analyzed through ANOVA. The effect of inoculation of EPS producing A. brasilense, B. subtilis, and their combinations in improving morphological (root and shoot length), physiological and biochemical attributes of two selected wheat varieties under control and drought stress conditions were also explored with ANOVA. The level selected for statistical significance was $p<0.05$ and post-hoc comparison Tukey Honest Significant Difference (HSD) was used for mean separation following ANOVA [39]. All statistical computations were performed on Statistix 8.1.

\section{Results}

\subsection{Soil Analysis and Bacterial Isolation}

Collected soil samples were sandy loam in texture with an electrical conductivity range of 15-16 dS/m, pH (8.0), and low nutrient concentration (Supplementary Table S1). Isolated bacterial strains were characterized based on colony morphology and characters (Supplementary Table S2). The isolated colonies were white to creamy and exhibited rough margins in the LB medium. 


\subsection{Phenotypic and Molecular Characterization of the Isolates}

These isolates were gram-negative and, vibroid or rod-shaped. All of the strains were able to grow up to $5 \%$ PEG; $90 \%$ of strains showed tolerance at $10 \%, 30 \%$, and $15 \%$ PEG, while only two strains i.e., A07 and B05 were able to grow at 20\% and 25\% PEG (Supplementary Table S3). These two strains also showed positive results for phosphorous solubilization, hydrogen cyanide, and siderophore production (Supplementary Table S4). Initially, these two strains were identified based on C/N source utilization pattern (Supplementary Table S5).

Molecular characterization of both strains was carried out by amplification of the 1500-bp region of $16 \mathrm{~S}$ rRNA and blast analysis of obtained nucleotides (Supplementary Table S6). The strain A07 (1400 nucleotides) showed a close similarity (98\%) to Azospirillum brasilense (Accession No. CP012917.1), whereas strain B05 (with 1480 nucleotides) had a sequence similarity $(99 \%)$ with Bacillus subtilis (Accession No.NC000964.3). The accession numbers of these two strains were obtained by NCBI and thus the isolated PGPR strains were identified as A. brasilense and B. subtilis respectively. The 16S rRNA gene sequences of these isolates were deposited in NCBI genebak with Accession No. MT742977 and MT742976 respectively.

\subsection{Drought Tolerance and Osmolytes in Bacterial Strains}

Drought tolerance of bacterial strains was done by using polyethylene glycol (PEG6000) (Table 1). Bacterial strains were subjected to two levels of osmotic stress i.e., $10 \%$ and $20 \%$ PEG. A high concentration of proline and sugar was observed at 20\% PEG in combination i.e., $37.5 \%$ proline and $45.8 \%$ sugar as compared to control. A. brasilense culture synthesized more amounts of osmolytes under osmotic stress ( $28.5 \%$ proline and $34.57 \%$ sugar) as compared to B. subtilis ( $15.38 \%$ proline and $31.1 \%$ sugar).

Table 1. Drought tolerance and osmolytes production (in $\mu \mathrm{g} / \mathrm{mg}$ ) of exopolysaccharides (EPS)-producing bacterial strains under osmotic stress conditions.

\begin{tabular}{ccccccc}
\hline \multirow{2}{*}{$\begin{array}{c}\text { Bacterial } \\
\text { Strains }\end{array}$} & \multicolumn{3}{c}{ Proline } & \multicolumn{3}{c}{ Sugar } \\
\cline { 2 - 7 } & Control & $\mathbf{1 0} \%$ PEG & 20\% PEG & Control & 10\% PEG & 20\% PEG \\
\hline B. subtilis & $2.6 \mathrm{~g} \pm 0.05$ & $2.8 \mathrm{f} \pm 0.07$ & $3 \mathrm{e} \pm 1.3$ & $47.29 \mathrm{i} \pm 3.2$ & $57 \mathrm{f} \pm 5.7$ & $62 \mathrm{~d} \pm 5.8$ \\
A. brasilense & $2.8 \mathrm{f} \pm 0.01$ & $3.4 \mathrm{c} \pm 0.04$ & $3.6 \mathrm{~b} \pm 0.06$ & $52.7 \mathrm{~h} \pm 7.4$ & $61 \mathrm{e} \pm 3.8$ & $71 \mathrm{~b} \pm 4.2$ \\
Combination & $3.2 \mathrm{~d} \pm 0.08$ & $3.7 \mathrm{~b} \pm 0.03$ & $4.4 \mathrm{a} \pm 0.04$ & $54.1 \mathrm{~g} \pm 5.3$ & $65 \mathrm{c} \pm 2.9$ & $79 \mathrm{a} \pm 9.3$ \\
\hline
\end{tabular}

Mean values of an osmolyte (proline) sharing different letters are significantly different $(p<0.05)$ from each other and vice versa.

\subsection{The EPS-Emulsification Activity of Bacterial Strains}

Results regarding EPS-emulsification activity (Table 2) revealed that strain Bacillus subtilis showed $45 \%$ and $32 \%$ activity after 30 and $60 \mathrm{~min}$, respectively. Whereas A. brasilense showed $42 \%$ and $30 \%$ EPS activities after 30 and $60 \mathrm{~min}$, respectively. The combination, however, retained $51 \%$ and $33 \%$ emulsification activity after 30 and $60 \mathrm{~min}$, respectively. The bacterial combination performed better than either of the single strains.

Table 2. The EPS-emulsification activity of B. subtilis, A. brasilense, and their combination are represented by mean \pm standard deviation values.

\begin{tabular}{ccc}
\hline \multirow{2}{*}{ Bacterial Strains } & \multicolumn{2}{c}{ Emulsifying Activity (\%) } \\
\cline { 2 - 3 } & After $\mathbf{3 0}$ min Incubation & After $\mathbf{6 0}$ min Incubation \\
\hline B. subtilis & $45 \mathrm{~b} \pm 2.4$ & $32 \mathrm{e} \pm 1.6$ \\
A. brasilense & $42 \mathrm{c} \pm 5.2$ & $30 \mathrm{f} \pm 1.8$ \\
Combination & $51 \mathrm{a} \pm 8.3$ & $33 \mathrm{~d} \pm 1.3$ \\
\hline Mean values carrying different letters are significantly different $(p<0.05)$ from each other
\end{tabular}

Mean values carrying different letters are significantly different $(p<0.05)$ from each other. 


\subsection{Solubility and Chemical Composition of EPS}

The lyophilized EPS were water-soluble but insoluble in acetone, benzene, chloroform, and ethanol. Results of the chemical composition of EPS showed that it mainly contained polysaccharides, protein, soluble sugar, and uronic acid content (Table 3). The uronic acid contents were less than protein and sugar in all EPS-producing strains.

Table 3. The EPS solubility and chemical composition of B. subtilis, A. brasilense, and their combination provided information of mean \pm standard deviation values.

\begin{tabular}{ccccc}
\hline Bacterial Strains & Polysaccharides $(\mathrm{mg} / \mathrm{g})$ & Protein $(\mu \mathrm{g} / \mathrm{g})$ & Soluble Sugar $(\mu \mathrm{g} / \mathrm{g})$ & Uronic Acid $(\mu \mathrm{g} / \mathrm{g})$ \\
\hline B. subtilis & $2.56 \mathrm{c} \pm 0.026$ & $720.3 \mathrm{c} \pm 36.4$ & $6954 \mathrm{~b} \pm 12.7$ & $1.1187 \mathrm{~b} \pm 0.06$ \\
A. brasilense & $4.07 \mathrm{~b} \pm 0.14$ & $740.2 \mathrm{~b} \pm 22.7$ & $6954 \mathrm{~b} \pm 31.8$ & $1.1187 \mathrm{~b} \pm 0.02$ \\
Combination & $5.73 \mathrm{a} \pm 0.43$ & $771.5 \mathrm{a} \pm 25.9$ & $6976 \mathrm{a} \pm 22.5$ & $1.1236 \mathrm{a} \pm 0.07$ \\
\hline
\end{tabular}

Mean values within a column having different letters are significantly different from each other and vice versa at $p<0.05$.

\subsection{Screening and Production of Phytohormones}

Bacterial strains were analyzed for phytohormones (Table 4) and the synthesis of IAA, Ck, GA, and $\mathrm{ABA}$ in stress and non-stress conditions was observed. A. brasilense showed a higher concentration of hormones compared to $B$. subtilis, while combination showed maximum production. There was a decrease in IAA, GA, and CK by $61 \%, 49 \%$, and $30 \%$ under stress but an increase of $27.29 \%$ in ABA concentration in osmotic stress (10\% PEG) compared to non-stress conditions.

Table 4. Phytohormones level in B. subtilis, A. brasilense, and their combination in $\mu \mathrm{g} / \mathrm{mL}$.

\begin{tabular}{ccccccccc}
\hline \multirow{2}{*}{ Bacterial Strain } & \multicolumn{2}{c}{ IAA } & \multicolumn{2}{c}{ GA } & \multicolumn{2}{c}{ CK } & \multicolumn{2}{c}{ ABA } \\
\cline { 2 - 8 } & Control & $\mathbf{2 0} \%$ PEG & Control & $\mathbf{2 0} \%$ PEG & Control & 20\% PEG & Control & 20\% PEG \\
\hline B. subtilis & $12.03 \mathrm{c} \pm 0.26$ & $3.79 \mathrm{e} \pm 0.05$ & $7.36 \mathrm{~d} \pm 0.015$ & $4.71 \mathrm{e} \pm 0.03$ & $3.5 \mathrm{c} \pm 0.09$ & $1.9 \mathrm{e} \pm 0.07$ & $23.09 \mathrm{e} \pm 0.52$ & $33.59 \mathrm{~d} \pm 2.08$ \\
A. brasilense & $23.15 \mathrm{~b} \pm 0.18$ & $7.23 \mathrm{~d} \pm 0.13$ & $18.74 \mathrm{~b} \pm 0.32$ & $10.15 \mathrm{c} \pm 0.21$ & $4.6 \mathrm{~b} \pm 0.08$ & $2.1 \mathrm{e} \pm 0.08$ & $36.13 \mathrm{~d} \pm 2.35$ & $61.03 \mathrm{c} \pm 3.19$ \\
Combination & $40.23 \mathrm{a} \pm 0.53$ & $12.49 \mathrm{c} \pm 0.08$ & $27.06 \mathrm{a} \pm 1.38$ & $19.13 \mathrm{~b} \pm 0.13$ & $5.1 \mathrm{a} \pm 0.1$ & $2.5 \mathrm{~d} \pm 0.08$ & $83.11 \mathrm{~b} \pm 5.08$ & $116.23 \mathrm{a} \pm 8.15$ \\
\hline
\end{tabular}

Mean values of phytohormone sharing different letters are significantly different $(p<0.05)$ from each other.

\subsection{Germination of Wheat}

Results related to the germination experiment (Supplementary Figure S1) showed that under osmotic stress (PEG 20\%) germination and germination related traits decreased. Seeds inoculated with bacterial strains showed a high germination percentage i.e., $18.24 \%$ and $15.78 \%$ under osmotic stress as compared to the control (un-inoculated seeds). Germination percentage (G\%), seedling vigor index (SVI) and promptness index (PI) values were high in combination-treated seeds as compared to single strain inoculated seeds. According to these findings, the treatments followed the pattern i.e., combination $>$ A. brasilense $>$ B. subtilis.

\subsection{Pot Experiment}

Results of the pot experiment showed that drought significantly reduced plant growth, and altered morphological, physiological, and biochemical processes. It also indicated better performance of combination for imparting drought tolerance in wheat, as compared to B. subtilis and A. brasilense alone.

\subsection{Morphological Responses of Wheat}

A significant difference $(p<0.05)$ was recorded in shoot length (Figure $1 \mathrm{~A})$ and root length of wheat (Figure 1B) treated with bacterial strains as compared to control in irrigated and drought exposed plants. The plants treated with combination showed significantly better results when compared with single bacterial strain inoculation. The increase due to combination was $42.89 \%$ and $41.31 \%$ in shoot length while $29.79 \%$ and $27.22 \%$ in root length in both varieties under drought as compared to un-inoculated plants facing drought stress. 

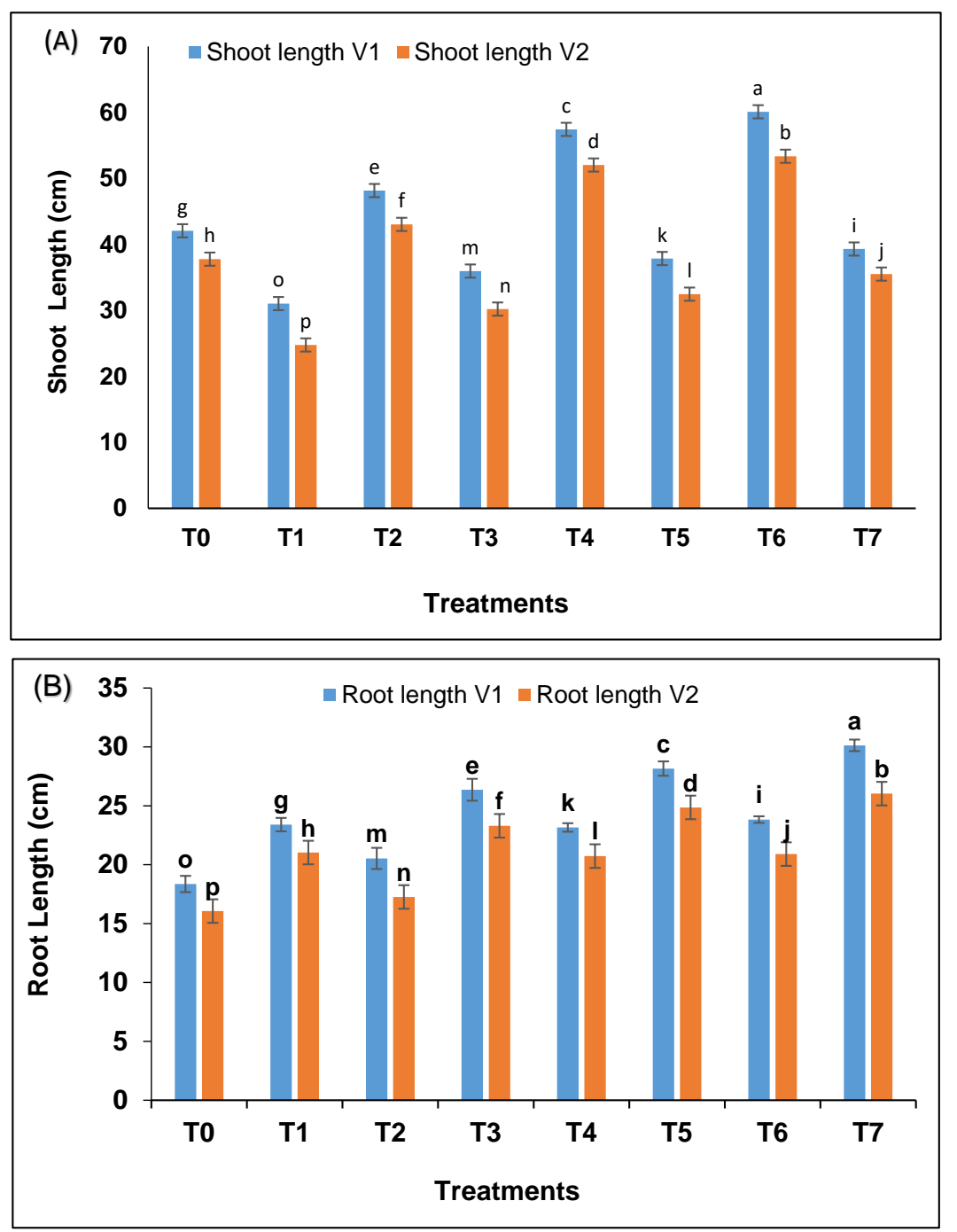

Figure 1. Effect of inoculation on $(\mathbf{A})$ shootlength $(\mathrm{cm})$ and $(\mathbf{B})$ root length $(\mathrm{cm})$ of two wheat varieties under control and droughtstress conditions. Where, $\mathrm{T} 0=$ control, $\mathrm{T} 1=$ drought stress, $\mathrm{T} 2=$ well-watered + B. subtilis, $\mathrm{T} 3=$ drought + B. subtilis, $\mathrm{T} 4=$ well-watered + A. brasilense, $\mathrm{T} 5=$ drought $+A$. brasilense, T6 = bacterial combination + well-watered, T7 = bacterial combination + drought, V1 = Pak 13 and V2 = NARC 09. Thecolumns anderror bars represent the mean values and standard deviations respectively whereas, different letters on mean values of either shoot or root length across seven treatments indicate significant difference at $p<0.05$.

\subsection{Physiological Responses of Wheat}

Leaf area decreased in drought stress whereas, in well-watered plants, leaves were comparatively larger and exhibited enlarged surface area (Figure 2). Bacterial combination-treated plants showed greater leaf area $\left(27.5 \mathrm{~cm}^{2}\right)$ followed by A. brasilense $\left(24.96 \mathrm{~cm}^{2}\right)$ and B. subtilis $\left(23.7 \mathrm{~cm}^{2}\right)$. 


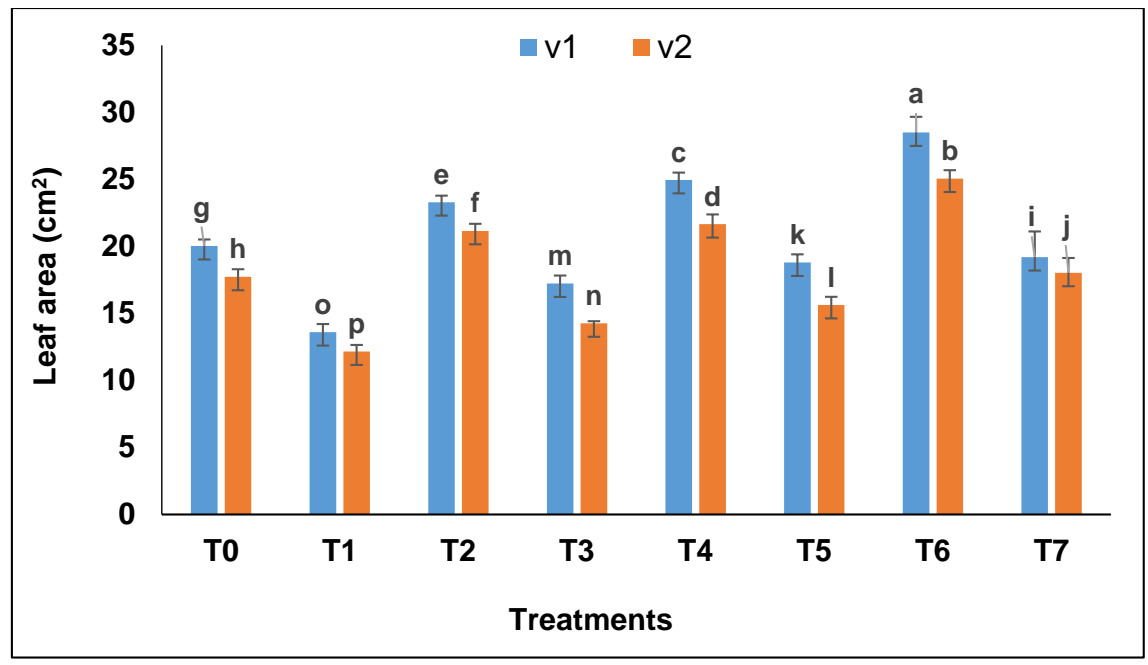

Figure 2. Effect of inoculation on leaf area $\left(\mathrm{cm}^{2}\right)$ of two wheat varieties under control and drought stress conditions. Where, $\mathrm{T} 0=$ control, $\mathrm{T} 1=$ drought stress, $\mathrm{T} 2=$ well-watered $+B$. subtilis, $\mathrm{T} 3=$ drought + B. subtilis, $\mathrm{T} 4=$ well-watered + A. brasilense, $\mathrm{T} 5=$ drought + A. brasilense, $\mathrm{T} 6=$ bacterial combination + well-watered, T7 = bacterial combination + drought, V1 = Pak 13 and V2 = NARC 09. The columns and error bars represent the mean values and standard deviations respectively whereas; different letters on mean values of leaf area indicate significant difference at $p<0.05$ and vice versa.

The membrane stability index (Figure 3) of drought-exposed plants decreased significantly as compared to control i.e., 30.12\% (Pak 13) and 34.61\% (NARC 09). Bacterial strains increased membrane stability and the increase recorded was higher in Pak 13 as compared to NARC 09 i.e., $29.48 \%$ and $24.17 \%$, respectively. The bacterial combination increased membrane stability efficiently as compared to single strains inoculation.

A. brasilense and B. subtilis inoculations also showed a positive response towards chlorophyll content (Table 5) as compared to control. Chlorophyll $a$ and $b$ content was higher in bacterial combination-treated plants in irrigated and drought exposed conditions. The increase in chlorophyll $\mathrm{a}, \mathrm{b}$ and total chlorophyll content in combination-treated plants was $39.8 \%, 61.49 \%$, and $45 \%$ as compared to control. Whereas A. brasilense and B. subtilis increased chlorophyll content by $31.14 \%$ and $18.62 \%$ respectively. The increase in chlorophyll content was higher in Pak 13 (45\%) as compared to NARC 09 (42.44\%).

Under drought, water potential was more negative i.e., $-2.2 \mathrm{MPa}$ as compared to control $-0.5 \mathrm{Mpa}$ (Figure 4A). Bacterial strains increased water potential in drought exposed plants to $-1.4 \mathrm{MPa}$ and $-1.5 \mathrm{MPa}$. A similar trend was observed for osmotic potential (Figure 4B). Pak 13 showed a better response as compared to NARC 09.

Table 5. Effect of inoculation on chlorophyll and carotenoid contents of two wheat varieties under control and drought stress conditions.

\begin{tabular}{ccccccc}
\hline \multirow{2}{*}{ Treatments } & \multicolumn{2}{c}{ Chlorophyll a $(\mathbf{m g} / \mathbf{g}$ FW) } & \multicolumn{2}{c}{ Chlorophyll b $\mathbf{( m g} / \mathbf{g}$ FW) } & \multicolumn{2}{c}{ Carotenoid (mg/g FW) } \\
\cline { 2 - 7 } & V1 & V2 & V1 & V2 & V1 & V2 \\
\hline T0 & $5.2 \mathrm{~g} \pm 0.99$ & $4.6 \mathrm{~h} \pm 0.84$ & $3.61 \mathrm{~g} \pm 0.083$ & $3.16 \mathrm{~h} \pm 0.13$ & $1.51 \mathrm{~g} \pm 0.09$ & $1.29 \mathrm{~h} \pm 0.12$ \\
T1 & $1.87 \mathrm{o} \pm 1.28$ & $1.6 \mathrm{p} \pm 1.15$ & $1.52 \mathrm{o} \pm 0.021$ & $1.11 \mathrm{p} \pm 0.04$ & $0.79 \mathrm{o} \pm 0.13$ & $0.64 \mathrm{p} \pm 0.18$ \\
T2 & $5.9 \mathrm{e} \pm 1.42$ & $5.7 \mathrm{f} \pm 1.29$ & $4.86 \mathrm{e} \pm 0.11$ & $4.11 \mathrm{f} \pm 0.11$ & $1.96 \mathrm{e} \pm 0.15$ & $1.71 \mathrm{f} \pm 0.13$ \\
T3 & $2.96 \mathrm{~m} \pm 1.51$ & $2.63 \mathrm{n} \pm 1.21$ & $2.71 \mathrm{~m} \pm 0.05$ & $2.21 \mathrm{n} \pm 0.03$ & $1.28 \mathrm{~m} \pm 0.14$ & $1.15 \mathrm{n} \pm 0.11$ \\
T4 & $6.46 \mathrm{c} \pm 1.58$ & $6.03 \mathrm{~d} \pm 1.38$ & $5.13 \mathrm{c} \pm 0.24$ & $4.83 \mathrm{~d} \pm 0.12$ & $2.2 \mathrm{c} \pm 0.16$ & $2.06 \mathrm{~d} \pm 0.14$ \\
T5 & $3.13 \mathrm{k} \pm 1.96$ & $2.631 \pm 1.71$ & $3.19 \mathrm{k} \pm 0.04$ & $2.95 \mathrm{l} \pm 0.06$ & $1.42 \mathrm{k} \pm 0.04$ & $1.291 \pm 0.16$ \\
T6 & $7.13 \mathrm{a} \pm 2.22$ & $6.83 \mathrm{~b} \pm 2.06$ & $6.1 \mathrm{a} \pm 0.08$ & $5.63 \mathrm{~b} \pm 0.13$ & $2.93 \mathrm{a} \pm 0.20$ & $2.76 \mathrm{~b} \pm 0.17$ \\
T7 & $4.6 \mathrm{i} \pm 2.93$ & $4.4 \mathrm{j} \pm 2.74$ & $3.71 \mathrm{i} \pm 0.05$ & $3.27 \mathrm{j} \pm 0.09$ & $1.58 \mathrm{i} \pm 0.18$ & $1.387 \mathrm{j} \pm 0.19$
\end{tabular}

Where, $\mathrm{T} 0=$ control, $\mathrm{T} 1=$ drought stress, $\mathrm{T} 2=$ well-watered + B. subtilis, $\mathrm{T} 3=$ drought + B. subtilis, $\mathrm{T} 4=$ well-watered $+A$. brasilense, $\mathrm{T} 5=$ drought $+A$. brasilense, $\mathrm{T} 6=$ bacterial combination + well-watered, $\mathrm{T} 7=$ bacterial combination + drought, $\mathrm{V} 1=$ Pak 13 and V2 = NARC 09. Thecolumns anderror bars represent the mean values and standard deviations respectively whereas; different letters on the mean values indicate significant difference at $p<0.05$. 


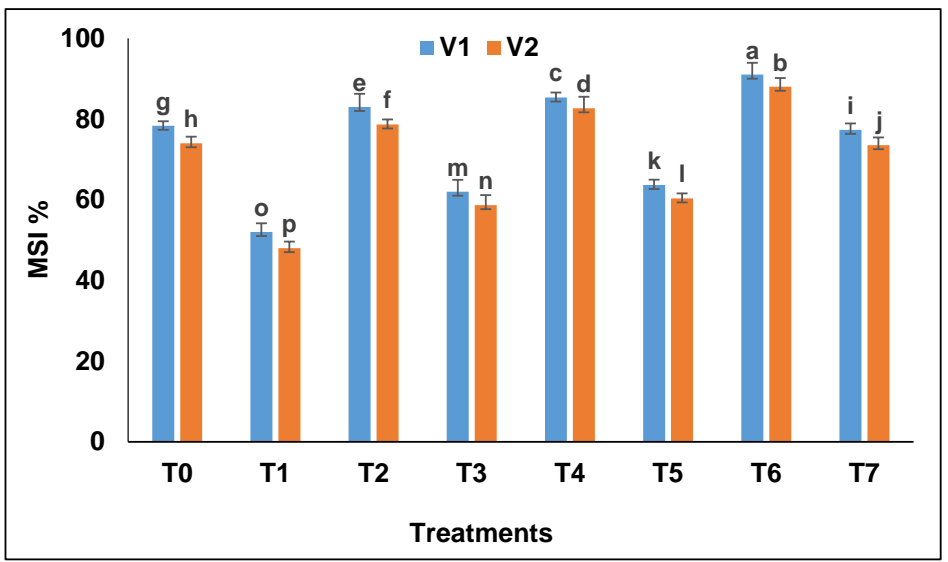

Figure 3. Effect of inoculation on membrane stability index (MSI) \% of two wheat varieties under control and drought stress conditions. Where, $\mathrm{T} 0=$ control, $\mathrm{T} 1=$ drought stress, $\mathrm{T} 2=$ well-watered $+B$. subtilis, $\mathrm{T} 3=$ drought + B. subtilis, $\mathrm{T} 4=$ well-watered + A. brasilense, $\mathrm{T} 5=\mathrm{drought}+$ A. brasilense, $\mathrm{T} 6=$ bacterial combination + well-watered, $\mathrm{T} 7=$ bacterial combination + drought, $\mathrm{V} 1=\mathrm{Pak} 13$ and V2 = NARC 09. The columns and error bars represent the mean values and standard deviations respectively whereas; different letters on mean values of MSI \% indicate significant difference at $p<0.05$ and vice versa.
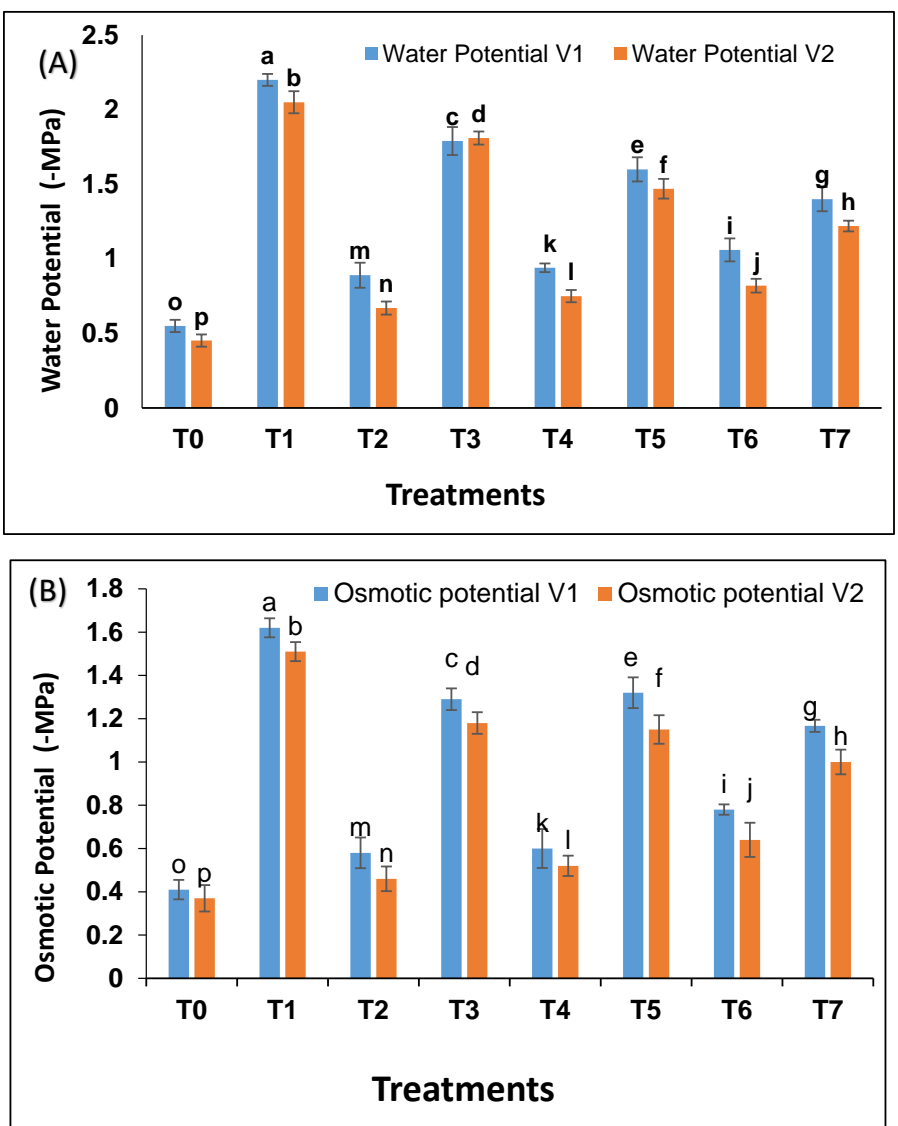

Figure 4. Effect of inoculation on (A) water potential and (B) osmotic potential of two wheat varieties under control and drought stressed conditions. Where, $\mathrm{T} 0=$ control, $\mathrm{T} 1=$ drought stress, $\mathrm{T} 2=$ well-watered + B. subtilis, $\mathrm{T} 3=$ drought + B. subtilis, $\mathrm{T} 4=$ well-watered + A. brasilense, $\mathrm{T} 5=$ drought + A. brasilense, T6 = bacterial combination + well-watered, T7 = bacterial combination + drought, V1 = Pak 13 and $\mathrm{V} 2=$ NARC 09. Thecolumns anderror bars represent the mean values and standard deviations respectively whereas; different letters on the mean values indicate significant difference at $p<0.05$. 


\subsection{Biochemical Responses of Wheat}

Bacterial strains significantly $(p<0.05)$ increased the concentration of the osmolytes i.e., proline, amino acids, protein, and sugar as compared to un-inoculated plants under drought stress. (Tables 6 and 7). The increase in proline content under drought was $14 \%, 28.12 \%$, and $30 \%$ in B. subtilis, A. brasilense, and combination-treated plants respectively. The bacterial combination resulted in the maximum accumulation of osmolytes followed by A. brasilense and B. subtilis. A similar trend was observed for protein, sugar, and amino acid content in plants.

Table 6. Effect of inoculation on amino acid and proline content of two wheat varieties under control and drought stress conditions.

\begin{tabular}{ccccc}
\hline \multirow{2}{*}{ Treatments } & \multicolumn{2}{c}{ Amino Acid $(\mathbf{m g} / \mathbf{g}$ FW) } & \multicolumn{2}{c}{ Proline $(\boldsymbol{\mu g} / \mathbf{g}$ FW) } \\
\cline { 2 - 5 } & $\mathbf{V 1}$ & $\mathbf{V 2}$ & $\mathbf{V 1}$ & V2 \\
\hline T0 & $0.25 \mathrm{o} \pm 0.018$ & $0.21 \mathrm{p} \pm 0.029$ & $32 \mathrm{o} \pm 5.71$ & $29 \mathrm{p} \pm 2.94$ \\
T1 & $0.69 \mathrm{~g} \pm 0.01$ & $0.65 \mathrm{~h} \pm 0.013$ & $106.66 \mathrm{~g} \pm 6.23$ & $101.66 \mathrm{~h} \pm 1.89$ \\
T2 & $0.35 \mathrm{~m} \pm 0.012$ & $0.31 \mathrm{n} \pm 0.015$ & $45.33 \mathrm{~m} \pm 2.86$ & $34 \mathrm{n} \pm 6.23$ \\
T3 & $0.75 \mathrm{e} \pm 0.017$ & $0.7 \mathrm{f} \pm 0.017$ & $135.66 \mathrm{e} \pm 5.43$ & $126.66 \mathrm{f} \pm 2.94$ \\
T4 & $0.41 \mathrm{k} \pm 0.016$ & $0.371 \pm 0.019$ & $56.33 \mathrm{k} \pm 2.86$ & $501 \pm 4.78$ \\
T5 & $0.82 \mathrm{c} \pm 0.019$ & $0.77 \mathrm{~d} \pm 0.014$ & $151 \mathrm{c} \pm 5.71$ & $143.33 \mathrm{~d} \pm 5.09$ \\
T6 & $0.49 \mathrm{i} \pm 0.012$ & $0.45 \mathrm{j} \pm 0.012$ & $71.33 \mathrm{i} \pm 3.39$ & $65.33 \mathrm{j} \pm 4.64$ \\
T7 & $0.9 \mathrm{a} \pm 0.018$ & $0.85 \mathrm{~b} \pm 0.016$ & $164.66 \mathrm{a} \pm 3.29$ & $155.33 \mathrm{~b} \pm 2.86$ \\
\hline
\end{tabular}

Where, $\mathrm{T} 0=$ Control, $\mathrm{T} 1=$ Drought stress, $\mathrm{T} 2=$ Well-watered + B. Subtilis, $\mathrm{T} 3=$ Drought + B. subtilis, $\mathrm{T} 4=$ Well-watered + A. brasilense, $\mathrm{T} 5=$ Drought + A . brasilense, $\mathrm{T} 6=$ Bacterial combination + Well-watered, $\mathrm{T} 7=$ Bacterial combination + Drought, V1 = Pak 13, V2 = NARC 09, FW = Fresh weight. The data presented as mean \pm standard deviation. Different letters with the mean values indicate significant difference at $p<0.05$ and vice versa.

Table 7. Effect of inoculation on sugar and protein content of two wheat varieties under control and drought stress conditions.

\begin{tabular}{ccccc}
\hline \multirow{2}{*}{ Treatments } & \multicolumn{2}{c}{ Soluble Sugars $(\mu \mathrm{g} / \mathrm{g}$ FW $)$} & \multicolumn{2}{c}{ Protein $(\mu \mathrm{g} / \mathrm{g}$ FW $)$} \\
\cline { 2 - 5 } & $\mathbf{V 1}$ & $\mathbf{V 2}$ & $\mathrm{V1}$ & $\mathrm{V} 2$ \\
\hline T0 & $11.33 \mathrm{o} \pm 1.24$ & $10.04 \mathrm{p} \pm 0.47$ & $2.47 \mathrm{o} \pm 0.14$ & $2.43 \mathrm{p} \pm 0.12$ \\
T1 & $21.13 \mathrm{~g} \pm 0.47$ & $19.48 \mathrm{~h} \pm 1.69$ & $3.31 \mathrm{~g} \pm 0.01$ & $3.18 \mathrm{~h} \pm 0.01$ \\
T2 & $13 \mathrm{~m} \pm 1.63$ & $12 \mathrm{n} \pm 1.63$ & $2.7 \mathrm{~m} \pm 0.21$ & $2.6 \mathrm{n} \pm 0.32$ \\
T3 & $25 \mathrm{e} \pm 0.81$ & $23.41 \mathrm{f} \pm 1.24$ & $3.87 \mathrm{e} \pm 0.2$ & $3.7 \mathrm{f} \pm 0.29$ \\
T4 & $15.33 \mathrm{k} \pm 1.24$ & $141 \pm 0.81$ & $3 \mathrm{k} \pm 0.37$ & $2.831 \pm 0.32$ \\
T5 & $27.93 \mathrm{c} \pm 0.89$ & $26.12 \mathrm{~d} \pm 2.05$ & $4.73 \mathrm{c} \pm 0.12$ & $4.36 \mathrm{~d} \pm 0.12$ \\
T6 & $17 \mathrm{i} \pm 0.81$ & $16.66 \mathrm{j} \pm 1.69$ & $3.16 \mathrm{i} \pm 0.26$ & $3.13 \mathrm{j} \pm 0.13$ \\
T7 & $31.42 \mathrm{a} \pm 1.24$ & $29.37 \mathrm{~b} \pm 2.62$ & $4.86 \mathrm{a} \pm 0.16$ & $4.53 \mathrm{~b} \pm 0.15$ \\
\hline
\end{tabular}

Where, $\mathrm{T} 0=$ Control, $\mathrm{T} 1=$ Drought stress, $\mathrm{T} 2=$ Well-watered + B. Subtilis, $\mathrm{T} 3=$ Drought + B. subtilis, $\mathrm{T} 4=$ Well-watered + A brasilense, $\mathrm{T} 5=$ Drought + A brasilense, $\mathrm{T} 6=$ Bacterial combination + Well-watered, $\mathrm{T} 7=$ Bacterial combination + Drought, V1 $=$ Pak 13, V2 = NARC 09, FW = Fresh weight. The data presented as mean \pm standard deviation. Different letters with the mean values indicate significant difference at $p<0.05$ and vice versa.

Bacterial strains also increased the production of amino acids in wheat under irrigated and drought stress conditions. The amino acid content increased up to $6.84 \%, 12.32 \%$, and $23.28 \%$ in inoculated plants as compared to un-inoculated drought exposed plants. The bacterial combination provided better results as compared to single strain inoculation. The increase in amino acid content was recorded high in Pak 13 (23.28\%) as compared to NARC 09 (21.53\%).

The increase in protein content was significant under drought stress as compared to control. Bacterial inoculation also increased protein synthesis in plants. Among inoculated plants, combination-treated plants showed better results with $46.82 \%$ and $42.45 \%$ increase as compared to untreated drought exposed plants. A. brasilense demonstrated better results as compared to B. subtilis in both wheat varieties.

Sugar production also increased under stress i.e., $26.18 \%$ and $21.44 \%$ as compared to control. Bacterial strains also increased the concentration of sugar, in wheat; the increase was $47.29 \%, 52.59 \%$, 
and $71.41 \%$ in Pak 13 and 45.94\%, 50.37\%, and 64.40\% in NARC 09 in B. subtilis, A. brasilense and combination inoculations respectively compared to control.

\subsection{Antioxidant Activities}

Drought stress increased the activities of antioxidants (Table 8) as compared to control. The increase in SOD was $14.25 \%, 25.71 \%$, and $35.71 \%$ in Pak 13 due to B. subtilis, A. brasilense and combination inoculation as compared to un-inoculated drought exposed plants whereas in NARC 09 the production increased by $10.29 \%, 22.05 \%$, and $33.05 \%$. It was noted that combination inoculation was more effective as compared to single strain inoculation.

Table 8. Effect of inoculation on antioxidants activity of two wheat varieties under control and drought stress conditions.

\begin{tabular}{ccccccc}
\hline \multirow{2}{*}{ Treatments } & \multicolumn{2}{c}{ SOD (Units/g FW) } & \multicolumn{2}{c}{ CAT (Units/g FW) } & \multicolumn{2}{c}{ POD (Units/g FW) } \\
\cline { 2 - 7 } & $\mathbf{V 1}$ & $\mathbf{V} \mathbf{2}$ & $\mathbf{V 1}$ & $\mathbf{V 2}$ & $\mathrm{V} 1$ & V2 \\
\hline T0 & $0.53 \mathrm{n} \pm 0.04$ & $0.43 \mathrm{o} \pm 0.1$ & $24.33 \mathrm{~m} \pm 1.2$ & $22.57 \mathrm{n} \pm 1.8$ & $28.33 \mathrm{o} \pm 1.6$ & $24.66 \mathrm{p} \pm 1.1$ \\
T1 & $1.4 \mathrm{~g} \pm 0.08$ & $1.36 \mathrm{~h} \pm 0.04$ & $51.33 \mathrm{~d} \pm 1.5$ & $43.57 \mathrm{~g} \pm 0.2$ & $59 \mathrm{~g} \pm 1.2$ & $48 \mathrm{~h} \pm 0.33$ \\
T2 & $1.031 \pm 0.09$ & $0.93 \mathrm{~m} \pm 0.04$ & $281 \pm 0.9$ & $26.961 \pm 1.3$ & $37 \mathrm{~m} \pm 0.8$ & $31.33 \mathrm{n} \pm 2.5$ \\
T3 & $1.6 \mathrm{e} \pm 0.07$ & $1.5 \mathrm{f} \pm 0.06$ & $56.33 \mathrm{c} \pm 1.4$ & $47.11 \mathrm{f} \pm 1.6$ & $65.33 \mathrm{e} \pm 1.2$ & $62.66 \mathrm{f} \pm 1.26$ \\
T4 & $1.2 \mathrm{j} \pm 0.06$ & $1.16 \mathrm{k} \pm 0.03$ & $38.33 \mathrm{i} \pm 2.16$ & $34 \mathrm{j} \pm 0.44$ & $41 \mathrm{k} \pm 1.1$ & $39.411 \pm 0.49$ \\
T5 & $1.76 \mathrm{c} \pm 0.03$ & $1.66 \mathrm{~d} \pm 0.05$ & $59 \mathrm{~b} \pm 1.47$ & $49.33 \mathrm{e} \pm 1.1$ & $73.66 \mathrm{c} \pm 1.2$ & $69.63 \mathrm{~d} \pm 1.6$ \\
T6 & $1.26 \mathrm{i} \pm 0.05$ & $1.2 \mathrm{j} \pm 0.04$ & $41.66 \mathrm{~h} \pm 0.1$ & $31.33 \mathrm{k} \pm 0.6$ & $47.33 \mathrm{i} \pm 0.6$ & $43.25 \mathrm{j} \pm 0.81$ \\
T7 & $1.9 \mathrm{a} \pm 0.06$ & $1.81 \mathrm{~b} \pm 0.03$ & $64.46 \mathrm{a} \pm 0.6$ & $57.03 \mathrm{c} \pm 1.2$ & $83 \mathrm{a} \pm 0.94$ & $77.51 \mathrm{~b} \pm 1.4$ \\
\hline
\end{tabular}

Where, $\mathrm{T} 0=$ Control, $\mathrm{T} 1=$ Drought stress, $\mathrm{T} 2=$ Well-watered + B. Subtilis, $\mathrm{T} 3=$ Drought + B. subtilis, $\mathrm{T} 4=$ Well-watered + A brasilense, $\mathrm{T} 5=$ Drought + A brasilense, $\mathrm{T} 6=$ Bacterial combination + Well-watered, $\mathrm{T} 7=$ Bacterial combination + Drought, V1 $=$ Pak 13, V2 = NARC 09, FW = Fresh weight. The data presented as mean \pm standard deviation. Different letters with the mean values indicate significant difference at $p<0.05$ and vice versa.

The CAT production increased up to $41.28 \%$ in drought exposed plants as compared to control. Inoculation of $B$. subtilis, A. brasilense, and combination increased catalase activity up to $55.05 \%, 62.40 \%$, and $77.42 \%$ in Pak13 and 29.89\%, 58.66\%, and $64.61 \%$ in NARC 09. However, Pak13 exhibited a higher level of antioxidants as compared to NARC 09.

Peroxidase production also increased for combating drought stress tolerance in wheat plants. Best results were obtained by combination inoculation in wheat i.e., 40.67\% increase in Pak13 and $25.02 \%$ in NARC 09 was observed compared to un-inoculated plants under stress.

\section{Discussion}

Drought stress has negative effects on wheat germination and growth. It was reported that PGPR increased the drought tolerance of plants. They colonize the rhizosphere and induce drought tolerance through various mechanisms like changes in root architecture, siderophore production, osmoregulation, production of phytohormones, regulations of antioxidants, and most importantly, the production of large chain extracellular polysaccharide (EPS) which improves plant growth [40]. The PGPR strains, B. subtilis and A. brasilense, were screened for their drought tolerance ability. Their EPS secreting ability was also tested. It was noted that the concentration of EPS was higher in stress (PEG6000) culture as compared to control conditions. Both strains produced a significant amount of EPS in a culture facing osmotic stress. The EPS are hydrated compounds with $97 \%$ water in the matrix which protects the bacteria as well as plants from desiccation. A wide variety of PGPR have been reported to produce EPS and they help crop plants in better root colonization, good seed germination, and stress tolerance [41]. They enhance water retention by maintaining the diffusion of organic carbon sources [42]. They consist of polysaccharides, proteins, soluble sugars, and uronic acid. In response to osmotic stress, bacterial strains also synthesize proline and soluble sugar. Upadhyay et al. [43] and Vardharajula et al. [44] also reported such results. In this study, it was observed that both strains synthesized a high concentration of phytohormones like IAA, GA, and ABA. The IAA facilitates cell division, elongation, and differentiation while GA and $\mathrm{ABA}$ act as a signaling molecule in plants facing 
stress conditions [45]. Synthesis of these hormones by bacterial strains imparts stress tolerance in plants [46].

A germination experiment was performed to check the ameliorative effect of selected bacterial strains. The germination parameters such as germination percentage, seedling vigor index, and promptness index decreased under high osmotic stress created by PEG 6000. Increased osmotic potential resulted in inhibition of water absorption by the seeds and impairment of other metabolic processes. In this study, bacterial combination increased germination and germination-related parameters significantly as compared to control. The EPS producing bacterial strains created a microenvironment that retained water and decreased osmotic stress. Under high osmotic stress, these stains synthesize extra amounts of EPS that alleviate the damage and increase the metabolic process in seeds [47]. Tewari and Arora [48] also reported a 50\% increase in germination rate by the inoculation of EPS producing bacterial strains under stress.

Drought stress decreased plant growth as the essential nutrients and solutes are diverted to stress-related functions [49]. However, bacterial inoculation increased the growth of the plant. In this study, it was noted that root/shoot length and leaf area was increased significantly by the inoculation of bacterial strains as compared to control [50]. Aslam et al. [51] also reported that under drought, rhizobacteria increased the leaf area of plants. Mishra et al. [52] also reported an increase in the growth of plants under stress by the inoculation of rhizobacteria. These results were also in harmony with Mahmoud et al. [53] and Kumari et al. [54]. Due to the EPS secreting ability of these bacterial strains they easily colonize plants rhizosphere, adhere to the root surface, and maintain moisture content. They have adhesive properties and make stable aggregates that increase nutrients and water availability, which in turn improves plant development and growth [55]. It has been reported that plants inoculated with EPS producing bacterial strains are more drought tolerant because these strains maintain soil aggregate stability and hold water contents which in turn increase plant growth [56].

The results of the present study revealed that B. subtilis and A. brasilense increased osmotic potential, water potential, and chlorophyll content in plants. Danish et al. [57] also reported that under drought stress PGPR inoculated plants showed higher chlorophyll contents as compared to un-inoculated drought-exposed plants. The maintenance of water and osmotic potential under stress conditions is similar to the previous study by Khan et al. [58].

Osmolytes accumulation in a plant is the key indicator of drought tolerance as it performs osmotic adjustment and prevents water loss [59]. Major osmolytes are proline, sugar, and protein under water stress [60]. An increase in amino acid concentration is another factor that contributes to drought tolerance [61]. Our results showed that the amount of these osmolytes increased significantly under drought stress. It is one of the defense strategies of bacterial strains to make plants drought tolerant. In the current research, it was noted that the increase in osmolyte concentration was significant in inoculated plants and it was obvious that the bacterial strains contributed significantly to plant growth promotion under water scarcity by enhancing their defense strategies [62].

In normal conditions, the ROS are produced in plant cells in negligible amounts and are scavenged, but when the plant is facing stress, their concentration increases which damage DNA, lipids, cell membrane, and cellular organelles. In short, ROS cause cellular toxicity in plants growing under any stress. To reduce the damaging effects of ROS, plants synthesize antioxidants. Measuring the activities of antioxidant enzymes reveals the involvement of the scavenging system during drought and also indicates how much treatments were effective under stress [63]. In the current study, inoculated plants showed a high concentration of antioxidants (SOD, CAT, and POD) as compared to un-inoculated plants under stress. Pak-13 (V1) showed a fair improvement in antioxidant activities as compared to NARC-09 (V2). Our results are in harmony with Zahir et al. [64] and Rezazadeh et al. [65]. Gowtham et al. [66] also reported a significant increase in antioxidant enzymes by the inoculation of bacterial strains under drought stress conditions. These antioxidants have the potential to minimize oxidative damage and make plant drought tolerant [67]. 


\section{Conclusions and Recommendations}

Application of EPS producing bacterial strains in crops is an environment-friendly strategy which ameliorates the adverse effects of drought stress in plants. These strains use different mechanisms like osmolyte production, phytohormones production, and antioxidants synthesis which induce drought tolerance in plants. The bacterial combination was recorded better in improving morphological, physiological, and biochemical parameters of wheat under drought and it can be used as a potential inoculant in arid agro-ecologies.

Supplementary Materials: The following are available online at http://www.mdpi.com/2071-1050/12/21/8876/s1, Table S1: Physicochemical Characteristics of Soil Sample, Table S2: Morphology of isolates from the arid region of Pakistan, Table S3: Screening for drought tolerance of isolated strains, Table S4: Characteristics of isolated strains, Table S5: Carbon/Nitrogen source utilization pattern determined by QTS-24 kits, Table S6: Molecular identification of the isolates based on partial 16S rDNA analysis, Figure S1: Effect of inoculation on germination parameters.

Author Contributions: N.I.: conceptualization, writing-original draft, supervision; K.M.: investigation, writing-original draft; N.A.: data analysis, writing-original draft; H.Y.: formal analysis, writing-review and editing; R.Z.S.: writing-review and editing; W.K.: formal analysis, writing-review, and editing; H.A.E.E.: facilitation, review, proofreading; D.J.D.: formatting, review, proofreading; E.A.E.: funding acquisition, proofreading; Z.A.: statistical analysis, proofreading. All authors have read and agreed to the published version of the manuscript.

Funding: This research was funded in part by the UTM-RMC grant, Malaysia. The authors are also thankful for King Saud University, Riyadh, Saudi Arabia for funding through Researchers Supporting Project (Project No. RSP-2020/52).

Conflicts of Interest: The authors declare no conflict of interest.

\section{References}

1. Sardouie-Nasab, S.; Mohammadi-Nejad, G.; Nakhoda, B. Yield Stability in Bread Wheat Germplasm across Drought Stress and Non-Stress Conditions. Agron. J. 2019, 111, 175-181. [CrossRef]

2. Pouri, K.; Mardeh, A.S.-S.; Sohrabi, Y.; Soltani, A. Crop phenotyping for wheat yield and yield components against drought stress. Curr. Res. Commun. 2019, 47, 383-393. [CrossRef]

3. Ullah, A.; Manghwar, H.; Shaban, M.; Khan, A.H.; Akbar, A.; Ali, U.; Ali, E.; Fahad, S. Phytohormones enhanced drought tolerance in plants: A coping strategy. Environ. Sci. Pollut. Res. 2018, 25, 33103-33118. [CrossRef] [PubMed]

4. Ghosh, D.; Sen, S.; Mohapatra, S. Modulation of proline metabolic gene expression in Arabidopsis thaliana under water-stressed conditions by a drought-mitigating Pseudomonas putida strain. Ann. Microbiol. 2017, 67, 655-668. [CrossRef]

5. Vurukonda, S.S.K.P.; Vardharajula, S.; Shrivastava, M.; Skz, A. Enhancement of drought stress tolerance in crops by plant growth promoting rhizobacteria. Microbiol. Res. 2016, 184, 13-24. [CrossRef]

6. Egamberdieva, D.; Wirth, S.J.; Alqarawi, A.A.; Allah, E.F.A.; Hashem, A. Phytohormones and Beneficial Microbes: Essential Components for Plants to Balance Stress and Fitness. Front. Microbiol. 2017, 8, 2104. [CrossRef]

7. Khan, N.; Bano, A. Exopolysaccharide producing rhizobacteria and their impact on growth and drought tolerance of wheat grown under rainfed conditions. PLoS ONE 2019, 9, e222302. [CrossRef]

8. Barnawal, D.; Singh, R.; Singh, R.P. Role of Plant Growth Promoting Rhizobacteria in Drought Tolerance. In PGPR Amelioration in Sustainable Agriculture; Elsevier BV: Amsterdam, The Netherlands, 2019; pp. 107-128.

9. Singh, R.P.; Jha, P.N. The Multifarious PGPR Serratia marcescens CDP-13 Augments Induced Systemic Resistance and Enhanced Salinity Tolerance of Wheat (Triticum aestivum L.). PLoS ONE 2016, 11, e0155026. [CrossRef]

10. Shameer, S.; Prasad, T.N.V.K.V. Plant growth promoting rhizobacteria for sustainable agricultural practices with special reference to biotic and abiotic stresses. Plant Growth Regul. 2018, 84, 603-615. [CrossRef]

11. Li, R.; Tao, R.; Ling, N.; Chu, G. Chemical, organic and bio-fertilizer management practices effect on soil physicochemical property and antagonistic bacteria abundance of a cotton field: Implications for soil biological quality. Soil Tillage Res. 2017, 167, 30-38. [CrossRef]

12. Jett, B.D.; Hatter, K.L.; Huycke, M.M.; Gilmore, M.S. Simplified Agar Plate Method for Quantifying Viable Bacteria. Biotechniques 1997, 23, 648-650. [CrossRef] [PubMed] 
13. Vincent, J.M.; Humphrey, B. Taxonomically Significant Group Antigens in Rhizobium. J. Gen. Microbiol. 1970, 63, 379-382. [CrossRef] [PubMed]

14. Pikovoskaya, R.I. Mobilization of phosphorus in soil in connection with vital activity of some microbial species. Mikrobiologiya 1948, 17, 362-370.

15. Patel, P.R.; Shaikh, S.S.; Sayyed, R.Z. Modified chrome azurol S method for detection and estimation of siderophores having affinity for metal ions other than iron. Environ. Sustain. 2018, 1, 81-87. [CrossRef]

16. Lorck, H. Production of Hydrocyanic Acid by Bacteria. Physiol. Plant. 1948, 1, 142-146. [CrossRef]

17. Bergey, D.H.; Holt, J.G.; Noel, R.K. Bergey's Manual of Systematic Bacteriology, 9th ed.; Williams \& Wilkins: Baltimore, MD, USA, 1994; Volume 1, pp. 1935-2045.

18. Chen, W.-P.; Kuo, T.-T. A simple and rapid method for the preparation of gram-negative bacterial genomic DNA. Nucleic Acids Res. 1993, 21, 2260. [CrossRef]

19. Weisburg, W.G.; Barns, S.M.; A Pelletier, D.; Lane, D.J. 16 S ribosomal DNA amplification for phylogenetic study. J. Bacteriol. 1991, 173, 697-703. [CrossRef]

20. Mishra, J.; Fatima, T.; Arora, N.K. Role of Secondary Metabolites from Plant Growth-Promoting Rhizobacteria in Combating Salinity Stress. In Microorganisms for Sustainability; Springer Science and Business Media LLC: Berlin/Heidelberg, Germany, 2018; pp. 127-163.

21. Hodge, J.E.; Hofreiter, B.R. Determination of reducing sugars and carbohydrates. In Methods in Carbohydrate Chemistry; Wilster, R.L., Wolfrom, M.L., Eds.; Academic Press: New York, NY, USA, 1962; pp. 380-394.

22. Rosenberg, E.; Zuckerberg, A.; Rubinovitz, C.; Gutnick, D.L. Emulsifier of Arthrobacter RAG-1: Isolation and emulsifying properties. Appl. Environ. Microbiol. 1979, 3, 402-408. [CrossRef]

23. Naseem, H.; Bano, A. Role of plant growth-promoting rhizobacteria and their exopolysaccharide in drought tolerance of maize. J. Plant Interact. 2014, 1, 689-701. [CrossRef]

24. Lowry, O.H.; Rosebrough, N.J.; Farr, A.L.; Randall, R.J. Protein measurement with the Folin phenol reagent. J. Biol. Chem. 1951, 193, 265-275. [PubMed]

25. Dubois, M.; Gilles, K.A.; Hamilton, J.K.; Rebers, P.A.; Smith, F. Colorimetric Method for Determination of Sugars and Related Substances. Anal. Chem. 1956, 28, 350-356. [CrossRef]

26. Taylor, K.A.; Buchanan-Smith, J.G. A colorimetric method for the quantitation of uronic acids and a specific assay for galacturonic acid. Anal. Biochem. 1992, 1, 190-196. [CrossRef]

27. Tien, T.M.; Gaskins, M.H.; Hubbell, D.H. Plant Growth Substances Produced by Azospirillum brasilense and Their Effect on the Growth of Pearl Millet (Pennisetum americanum L.). Appl. Environ. Microbiol. 1979, 37, 1016-1024. [CrossRef] [PubMed]

28. Sairam, R.K.; Saxena, D.C. Oxidative Stress and Antioxidants in Wheat Genotypes: Possible Mechanism of Water Stress Tolerance. J. Agron. Crop. Sci. 2000, 184, 55-61. [CrossRef]

29. Bruuinsma, J. The quantitative analysis of chlorophylls a and b in plant extracts. Photochem. Photobiol. 1963, 2, 241-249. [CrossRef]

30. Scholander, P.F.; Bradstreet, E.D.; Hemmingsen, E.A.; Hammel, H.T. Sap Pressure in Vascular Plants: Negative hydrostatic pressure can be measured in plants. Science 1965, 3668, 339-346. [CrossRef]

31. Capell, B.; Dorffling, K. Genotype-specific differences in chilling tolerance of maize in relation to chilling-induced changes in water status and abscisic acid accumulation. Physiol. Planta. 1993, 88, 638-646. [CrossRef] [PubMed]

32. Bates, L.S.; Waldren, R.P.; Teare, I.D. Rapid determination of free proline for water-stress studies. Plant Soil 1973, 39, 205-207. [CrossRef]

33. Hamilton, P.B.; Van Slyke, D.D. Amino acid determination with ninhydrin. J. Biol. Chem. 1943, 150, $231-250$.

34. Bradford, M. A rapid and sensitive method for the quantitation of microgram, quantitation of proteins utilizing the principle of protein dye-binding. Anal. Biochem. 1976, 72, 248-254. [CrossRef]

35. Dubois, M.; Gilles, K.; Hamilton, J.K.; Rebers, P.A.; Smith, F. A Colorimetric Method for the Determination of Sugars. Nat. Cell Biol. 1951, 168, 167. [CrossRef] [PubMed]

36. Beauchamp, C.; Fridovich, I. Superoxide dismutase: Improved assays and an assay applicable to acrylamide gels. Anal. Biochem. 1971, 44, 276-287. [CrossRef]

37. Cakmak, I.; Marschner, H. Magnesium Deficiency and High Light Intensity Enhance Activities of Superoxide Dismutase, Ascorbate Peroxidase, and Glutathione Reductase in Bean Leaves. Plant Physiol. 1992, 98, 1222-1227. [CrossRef] 
38. Zhang, J.; Kirkham, M. Drought-Stress-Induced Changes in Activities of Superoxide Dismutase, Catalase, and Peroxidase in Wheat Species. Plant Cell Physiol. 1994, 35, 785-791. [CrossRef]

39. David, F.N.; Steel, R.G.D.; Torrie, J.H. Principles and Procedures of Statistics. A Biomaterial Approach, 3rd ed.; McGraw Hill: New York, NY, USA, 1997.

40. Sayyed, R.Z.; Jamadar, D.D.; Patel, P.R. Production of Exo-polysaccharide by Rhizobium sp. Indian J. Microbiol. 2011, 51, 294-300. [CrossRef] [PubMed]

41. Etesami, H.; Adl, S.M. Plant Growth-Promoting Rhizobacteria (PGPR) and Their Action Mechanisms in Availability of Nutrients to Plants. In Environmental and Microbial Biotechnology; Springer Science and Business Media LLC: Berlin/Heidelberg, Germany, 2020; pp. 147-203.

42. Yasmin, F.; Othman, R.; Maziz, M.N.H. Yield and Nutrient Content of Sweet Potato in Response of Plant Growth-Promoting Rhizobacteria (PGPR) Inoculation and N Fertilization. Jordan J. Biol. Sci. 2020, 13, 117-122.

43. Upadhyay, S.K.; Singh, J.; Singh, D. Exopolysaccharide-Producing Plant Growth-Promoting Rhizobacteria Under Salinity Condition. Pedosphere 2011, 21, 214-222. [CrossRef]

44. Vardharajula, S.; Ali, S.Z.; Grover, M.; Reddy, G.; Bandi, V. Drought-tolerant plant growth promotingBacillusspp.: Effect on growth, osmolytes, and antioxidant status of maize under drought stress. J. Plant Interact. 2011, 6, 1-14. [CrossRef]

45. Vijay, R.; Ravichandran, V.; Boominathan, P. Screening of Rice Apoplast Associated Endophytic Bacterial Isolates for Moisture Stress Tolerance and Plant Growth Promoting Traits. Madras Agric. J. 2019, 106, 5-11.

46. Ghosh, D.; Gupta, A.; Mohapatra, S. A comparative analysis of exopolysaccharide and phytohormone secretions by four drought-tolerant rhizobacterial strains and their impact on osmotic-stress mitigation in Arabidopsis thaliana. World J. Microbiol. Biotechnol. 2019, 35, 90. [CrossRef]

47. Bakhshandeh, E.; GholamHosseini, M.; Yaghoubian, Y.; Pirdashti, H. Plant growth promoting microorganisms can improve germination, seedling growth and potassium uptake of soybean under drought and salt stress. Plant Growth Regul. 2019, 1, 123-136. [CrossRef]

48. Tewari, S.; Arora, N.K. Multifunctional Exopolysaccharides from Pseudomonas aeruginosa PF23 Involved in Plant Growth Stimulation, Biocontrol and Stress Amelioration in Sunflower Under Saline Conditions. Curr. Microbiol. 2014, 4, 484-494. [CrossRef] [PubMed]

49. Brestic, M.; Zivcak, M.; Hauptvogel, P.; Misheva, S.; Kocheva, K.; Yang, X.; Li, X.; Allakhverdiev, S.I. Wheat plant selection for high yields entailed improvement of leaf anatomical and biochemical traits including tolerance to non-optimal temperature conditions. Photosynth. Res. 2018, 2, 245-255. [CrossRef]

50. Lin, Y.; Watts, D.B.; Kloepper, J.W.; Feng, Y.; Torbert, H.A. Influence of Plant Growth-Promoting Rhizobacteria on Corn Growth under Drought Stress. Commun. Soil Sci. Plant Anal. 2020, 51, 250-264. [CrossRef]

51. Aslam, M.U.; Raza, M.A.S.; Saleem, M.F.; Waqas, M.; Iqbal, R.; Ahmad, S.; Haider, I. Improving Strategic Growth Stage-based Drought Tolerance in Quinoa by Rhizobacterial Inoculation. Commun. Soil Sci. Plant Anal. 2020, 51, 853-868. [CrossRef]

52. Mishra, S.K.; Khan, M.H.; Misra, S.; Dixit, V.K.; Gupta, S.; Tiwari, S.; Gupta, S.C.; Chauhan, P. Drought tolerant Ochrobactrum sp. inoculation performs multiple roles in maintaining the homeostasis in Zea mays L. subjected to deficit water stress. Plant Physiol. Biochem. 2020, 150, 1-14. [CrossRef]

53. Ben Mahmoud, O.M.; Hidri, R.; Talbi-Zribi, O.; Taamalli, W.; Abdelly, C.; Djébali, N. Auxin and proline producing rhizobacteria mitigate salt-induced growth inhibition of barley plants by enhancing water and nutrient status. S. Afr. J. Bot. 2020, 128, 209-217. [CrossRef]

54. Kumari, S.; Vaishnav, A.; Jain, S.; Varma, A.; Johri, B.N. Induced drought tolerance through wild and mutant bacterial strain Pseudomonas simiae in mung bean (Vigna radiata L.). World J. Microbiol. Biotechnol. 2016, 32, 1-10. [CrossRef]

55. Tewari, S.; Sharma, S. Rhizobial exopolysaccharides as supplement for enhancing nodulation and growth attributes of Cajanus cajan under multi-stress conditions: A study from lab to field. Soil Tillage Res. 2020, 198, 104545. [CrossRef]

56. Asghari, B.; Khademian, R.; Sedaghati, B. Plant growth promoting rhizobacteria (PGPR) confer drought resistance and stimulate biosynthesis of secondary metabolites in pennyroyal (Mentha pulegium L.) under water shortage condition. Sci. Hortic. 2020, 263, 109132. [CrossRef] 
57. Danish, S.; Zafar-Ul-Hye, M.; Mohsin, F.; Hussain, M. ACC-deaminase producing plant growth promoting rhizobacteria and biochar mitigate adverse effects of drought stress on maize growth. PLOS ONE 2020, 4, e0230615. [CrossRef] [PubMed]

58. Khan, N.; Bano, A.; Zandi, P. Effects of exogenously applied plant growth regulators in combination with PGPR on the physiology and root growth of chickpea (Cicer arietinum) and their role in drought tolerance. J. Plant Interact. 2018, 1, 239-247. [CrossRef]

59. Vaishnav, A.; Choudhary, D.K. Regulation of Drought-Responsive Gene Expression in Glycine max L. Merrill is Mediated through Pseudomonas simiae Strain AU. J. Plant Growth Regul. 2018, 38, 333-342. [CrossRef]

60. Karimzadeh, J.; Alikhani, H.A.; Etesami, H.; Pourbabaei, A.A. Improved Phosphorus Uptake by Wheat Plant (Triticum aestivum L.) with Rhizosphere Fluorescent Pseudomonads Strains under Water-Deficit Stress. J. Plant Growth Regul. 2020, 1-17. [CrossRef]

61. Askari, E.; Ehsanzadeh, P. Drought stress mitigation by foliar application of salicylic acid and their interactive effects on physiological characteristics of fennel (Foeniculum vulgare Mill.) genotypes. Acta Physiol. Plant. 2015, 4, 1-14. [CrossRef]

62. Chiappero, J.; Cappellari, L.D.R.; Alderete, L.G.S.; Palermo, T.B.; Banchio, E. Plant growth promoting rhizobacteria improve the antioxidant status in Mentha piperita grown under drought stress leading to an enhancement of plant growth and total phenolic content. Ind. Crop. Prod. 2019, 139, 111-553. [CrossRef]

63. Damodaran, T.; Rai, R.; Jha, S.; Kannan, R.; Pandey, B.; Sah, V.; Mishra, V.K.; Sharma, D. Rhizosphere and endophytic bacteria for induction of salt tolerance in gladiolus grown in sodic soils. J. Plant Interact. 2014, 1, 577-584. [CrossRef]

64. Zahir, A.; Abbasi, B.H.; Adil, M.; Anjum, S.; Zia, M.; Ihsan-ul-haq. Synergistic Effects of Drought Stress and Photoperiods on Phenology and Secondary Metabolism of Silybum marianum. Appl. Biochem. Biotechnol. 2014, 174, 693-707. [CrossRef]

65. Rezazadeh, S.; Aghayari, F.; Paknejad, F.; Rezaee, M. The physiological and biochemical responses of directly seeded and transplanted maize (Zea mays L.) supplied with plant growth-promoting rhizobacteria (PGPR) under water stress. Plant Physiol. 2019, 1, 3009-3021.

66. Gowtham, H.G.; Singh, B.; Murali, M.; Shilpa, N.; Prasad, M.; Aiyaz, M.; Niranjana, S.R. Induction of drought tolerance in tomato upon the application of ACC deaminase producing plant growth promoting rhizobacterium Bacillus subtilis Rhizo SF 48. Microbiol. Res. 2020, 234, 126422. [CrossRef]

67. Sagar, A.; Sayyed, R.; Ramteke, P.W.; Sharma, S.; Marraiki, N.; Elgorban, A.M.; Syed, A. ACC deaminase and antioxidant enzymes producing halophilic Enterobacter sp. PR14 promotes the growth of rice and millets under salinity stress. Physiol. Mol. Biol. Plants 2020, 26, 1847-1854. [CrossRef] [PubMed]

Publisher's Note: MDPI stays neutral with regard to jurisdictional claims in published maps and institutional affiliations.

(C) 2020 by the authors. Licensee MDPI, Basel, Switzerland. This article is an open access article distributed under the terms and conditions of the Creative Commons Attribution (CC BY) license (http://creativecommons.org/licenses/by/4.0/). 